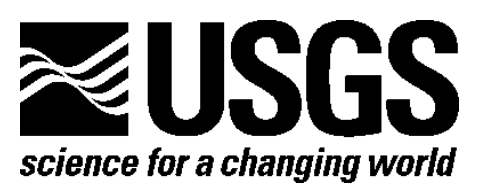

\title{
A Field Trip Guidebook to the Type Localities of Marland Billings' 1935 Paleozoic Bedrock Stratigraphy Near Littleton, New Hampshire
}

By Douglas W. Rankin and Mary B. Rankin

Open-File Report 2014-1026

U.S. Department of the Interior

U.S. Geological Survey 


\section{U.S. Department of the Interior SALLY JEWELL, Secretary}

\section{U.S. Geological Survey \\ Suzette M. Kimball, Acting Director}

U.S. Geological Survey, Reston, Virginia: 2014

For more information on the USGS-the Federal source for science about the Earth, its natural and living resources, natural hazards, and the environment-visit http://www.usgs.gov or call 1-888-ASK-USGS (1-888-275-8747)

For an overview of USGS information products, including maps, imagery, and publications, visit http://www.usgs.gov/pubprod

To order this and other USGS information products, visit http://store.usgs.gov

The field trip described in this report was led on March 17, 2013.

Any use of trade, firm, or product names is for descriptive purposes only and does not imply endorsement by the U.S. Government.

Although this information product, for the most part, is in the public domain, it also may contain copyrighted materials as noted in the text. Permission to reproduce copyrighted items must be secured from the copyright owner.

Suggested citation:

Rankin, D.W., and Rankin, M.B., 2014, A field trip guidebook to the type localities of Marland Billings' 1935 Paleozoic bedrock stratigraphy near Littleton, New Hampshire: U.S. Geological Survey Open-File Report 2014-1026, 21 p., http://dx.doi.org/10.3133/ofr20141026.

ISSN 2331-1258 (online) 


\section{Contents}

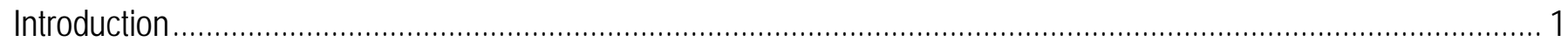

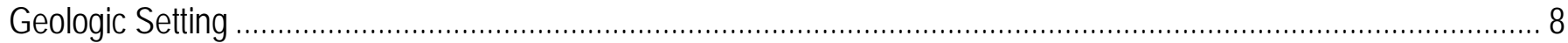

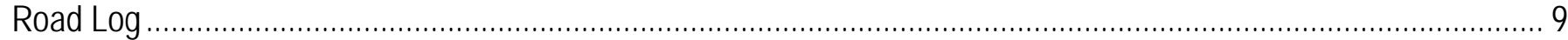

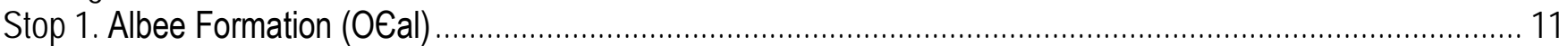

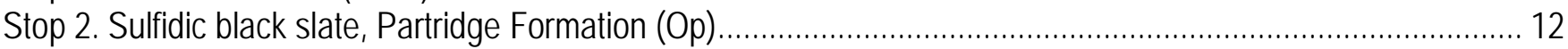

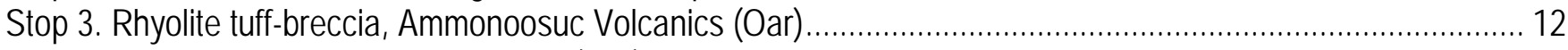

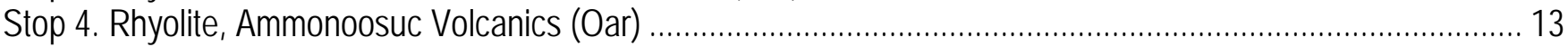

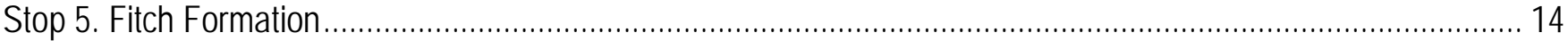

Stop 6. Pelitic facies of the Littleton Formation (DI) ..................................................................................... 14

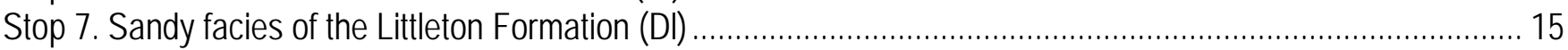

Stop 8. Rhyolite/mudstone debris flow interlayered with rhyolite aphanitic tuff and black slate (Oar) ................... 16

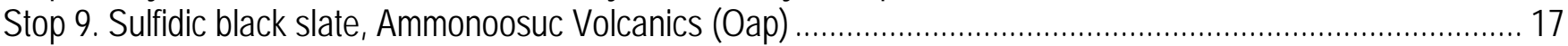

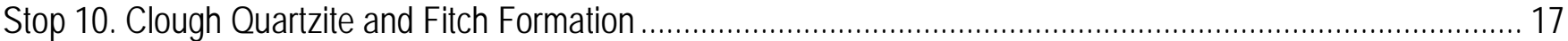

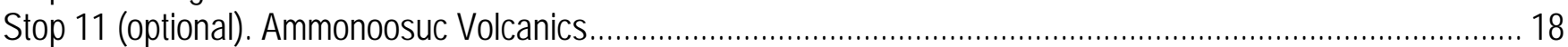

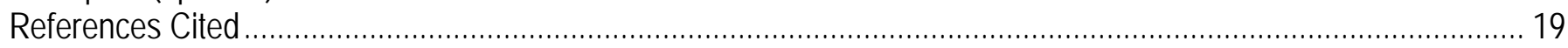

\section{Figures}

1. Geologic map of the Littleton 15-minute quadrangle, New Hampshire .............................................5

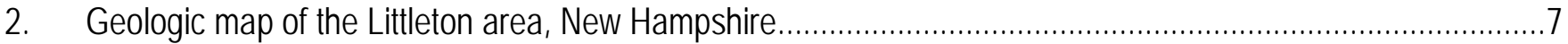

3. Topographic map of the Littleton area, New Hampshire ............................................................

\section{Table}

1. Description of map units in the Littleton-Moosilauke area, New Hampshire. .............................................2 


\section{Conversion Factors}

Inch/Pound to SI

\begin{tabular}{lcll}
\hline & Multiply & By & To obtain \\
\hline inch (in.) & Length & \\
inch (in.) & 2.54 & centimeter (cm) \\
foot (ft) & 25.4 & millimeter (mm) & \\
mile (mi) & 0.3048 & meter (m) \\
yard (yd) & 1.609 & kilometer $(\mathrm{km})$ \\
& 0.9144 & meter $(\mathrm{m})$ \\
\hline square mile $\left(\mathrm{mi}^{2}\right)$ & Area & \\
\hline
\end{tabular}

SI to Inch/Pound

\begin{tabular}{llll}
\hline & Multiply & & To obtain \\
\hline & Length & & \\
\hline centimeter $(\mathrm{cm})$ & 0.3937 & inch (in.) & \\
millimeter (mm) & 0.03937 & inch (in.) & \\
meter (m) & 3.281 & foot (ft) & \\
kilometer $(\mathrm{km})$ & 0.6214 & mile (mi) \\
meter $(\mathrm{m})$ & 1.094 & yard (yd) & \\
\hline & Area & & \\
\hline square kilometer $\left(\mathrm{km}^{2}\right)$ & 0.3861 & square mile $\left(\mathrm{mi}^{2}\right)$ &
\end{tabular}




\title{
A Field Trip Guidebook to the Type Localities of Marland Billings' 1935 Paleozoic Bedrock Stratigraphy Near Littleton, New Hampshire
}

\author{
By Douglas W. Rankin and Mary B. Rankin
}

\section{Introduction}

During the course of his Ph.D. research at Harvard University on the geology of the North Conway quadrangle, Billings (1928) puzzled over the age of the metasedimentary gneisses and schists (his Montalban schists) that were host to the plutonic rocks. When he returned to Harvard as an assistant professor in 1931, after a stint of teaching at Bryn Mawr College, he looked for a place in which field mapping might shed light on the problem. He chose the Littleton area, then the only terrain in New Hampshire known to contain Paleozoic fossils. Coinciding with the early stages of this work, he provided George W. Stose of the U.S. Geological Survey an interpretive map of the geology of central New Hampshire (Billings, 1934). Based largely on this map, central New Hampshire is shown on the 1932 geologic map of the United States as "pre-Cambrian, some early Paleozoic rocks may be included" (Stose and Ljungstedt, 1932). Thus it was Billings who made that call and Billings who almost immediately changed it.

With the assistance of two or three graduate students each year, Billings completed the geologic mapping of the New Hampshire part of the Littleton 15-minute quadrangle as well as the entire Moosilauke 15-minute quadrangle (which adjoins Littleton to the south) in a little over three summers. The New Hampshire State Planning and Development Commission published the maps along with the definitions of stratigraphic units in 1935 (Billings, 1935). The maps and a much expanded text appeared in the Geological Society of America Bulletin (Billings, 1937) in what has become a classic paper demonstrating that the simultaneous application of the principles of stratigraphy, structural geology, and igneous and metamorphic petrology to the mapping of outcrops could lead to breakthroughs in regional interpretations. In the words of Walter White (1968), this work provided the stratigraphic key to the geology of western New Hampshire, and laid the foundation upon which a major part of subsequent work in New England has been directly or indirectly built.

Billings established and named a succession of six stratigraphic units in the rocks of low metamorphic grade west of Littleton (the Littleton Formation, Fitch Formation, Clough Quartzite, Partridge Formation, Ammonoosuc Volcanics, and Albee Formation; see table 1). The two youngest units, the calcareous Fitch Formation and the turbiditic Littleton Formation, are fossiliferous in the area, with ages established by Billings and Cleaves (1934) as “middle” Silurian and Early Devonian, respectively. The Clough Quartzite, which underlies the Fitch, provided structural control. According to Billings (1935, p. 13), “The Clough Conglomerate (now Quartzite) is undoubtedly the best key horizon in western New Hampshire. It is very distinctive, readily recognized, thin but resistant, and most invariably outcrops wherever it exists. A study of the geologic structure of the area resolves itself in part into a careful mapping of the Clough.” Billings and students recognized and mapped the same 
stratigraphic section, or parts thereof, with units in the same stratigraphic order where not disturbed by faulting, in adjacent areas of progressively higher regional metamorphic grade to the east and south. The Littleton Formation in parts of the Moosilauke quadrangle contains the assemblage muscovitesillimanite. Finally, Billings and Cleaves (1934) described a brachiopod identified as Spirifer sp. ind. from the sillimanite-bearing rocks near Mount Moosilauke.

Table 1. Description of map units in the Littleton-Moosilauke area, New Hampshire.

[Map units are shown in figure 2. Abbreviations: mm, millimeter; $\mathrm{cm}$, centimeter; km, kilometer]

\begin{tabular}{lll}
\hline \multicolumn{1}{c}{ Formation } & Map unit & \multicolumn{1}{c}{ Description } \\
\hline Stratified rocks & Eastern Vermont Sequence \\
$\begin{array}{l}\text { Gile Mountain } \\
\text { Formation }\end{array}$ & Dg & $\begin{array}{l}\text { Interlayered light-gray to tan micaceous metasandstone and } \\
\text { medium- to dark-gray to grayish-black, graphitic and commonly } \\
\text { sulfidic slate. Minor calcareous metasandstone and calcareous } \\
\text { ironstone. Graded bedding common. }\end{array}$ \\
$\begin{array}{l}\text { Meetinghouse } \\
\text { Slate Member }\end{array}$ & Dgm & $\begin{array}{l}\text { Medium-dark-gray to grayish-black slate containing sparse to } \\
\text { moderately abundant 1-mm- to 1-cm-thick beds of light-gray, } \\
\text { fine-grained metasandstone and metasiltstone, commonly sulfidic } \\
\text { and calcareous. Some graded bedding. Gradational contact with } \\
\text { Dg. }\end{array}$ \\
& & Boundary Mountains-Bronson Hill Sequence \\
\hline
\end{tabular}

Stratified rocks

Littleton Dl Medium-dark-gray to dark-gray slate and schist interlayered with

Formation light-gray, fine-grained micaceous metasandstone. Sparse grit.

Lower Devonian Locally highly pyritic and rusty weathering, with pyrite crystals as large as $2 \mathrm{~cm}$. Contains mappable units of mafic and felsic volcanic and volcaniclastic rocks; includes Dlr, which consists of metamorphosed aphanitic to very fine grained tuff, welded tuff, lithic tuff (commonly with a few percent quartz and alkali feldspar phenocrysts), and volcanic conglomerate. (Dlr is not shown in figure 2.)

Fitch Formation Sfc Sitch Formation and Clough Quartzite, undivided.

and Clough

Quartzite

Fitch Formation: Metamorphosed limestone, calcareous (Emsian: Walker Mtn.; Pragian: Mt. Moosilauke) sandstone, siltstone, and pelite. Some limestone conglomerate and polymict conglomerate with calcareous matrix.

Upper Silurian (Pridolian)

Clough Quartzite: Metamorphosed quartz-cobble to -pebble conglomerate, quartzite, and micaceous sandstone.

Lower Silurian (Llandoverian)

Partridge Op

Formation

Dark-gray to grayish-black, rusty-weathering, sulfidic slate interlayered locally with metamorphosed rhyolite (Opr). Where

Upper Ordovician the sulfide is pyrrhotite as opposed to pyrite, rusty weathering is pronounced ("cruddy black slate”).

Ammonoosuc Volcanics

Metamorphosed felsic and mafic volcanic and volcaniclastic rocks, pelite, and ironstone.

Middle and Upper Ordovician 
Table 1. Description of map units in the Littleton-Moosilauke area, New Hampshire.-Continued

[Map units are shown in figure 2. Abbreviations: mm, millimeter; cm, centimeter; km, kilometer]

\begin{tabular}{|c|c|c|c|}
\hline Formation & Map unit & Description & Age \\
\hline \multicolumn{4}{|c|}{ Boundary Mountains-Bronson Hill Sequence-Continued } \\
\hline & Oar & $\begin{array}{l}\text { Dominantly metamorphosed rhyolite tuff, lapilli tuff, tuff- } \\
\text { breccia, and lava. Generally porphyritic with } 5 \text { to } 20 \text { percent } \\
\text { plagioclase and, in some, quartz phenocrysts. Generally strongly } \\
\text { foliated with waxy sheen on foliation surfaces. Includes } \\
\text { mappable units (not shown) of coarsely porphyritic rhyolite tuff, } \\
\text { lapilli tuff, and tuff-breccia, in which quartz and plagioclase } \\
\text { phenocrysts are commonly as large as } 5 \mathrm{~mm} \text {. }\end{array}$ & \\
\hline & Oaа & $\begin{array}{l}\text { Dominantly metamorphosed andesitic and basaltic tuff, crystal } \\
\text { tuff, and tuff-breccia; minor pillow lava. Commonly contains } \\
\text { relict plagioclase and (or) mafic phenocrysts. }\end{array}$ & \\
\hline & Oat & $\begin{array}{l}\text { Metamorphosed medium- to light-bluish-gray aphyric rhyolite } \\
\text { tuff and siltstone. }\end{array}$ & \\
\hline & $\begin{array}{l}\text { Oad } \\
(=\mathrm{Sfc})\end{array}$ & $\begin{array}{l}\text { Metamorphosed light-bluish-gray, rusty-weathering, siliceous } \\
\text { and argillaceous dolomite and calcareous siltstone. } \\
\text { Now reinterpreted as Fitch Formation. Reassigned to the Fitch } \\
\text { Formation. }\end{array}$ & \\
\hline & Oam & $\begin{array}{l}\text { Metamorphosed medium-light-bluish-gray, medium-bluish-gray, } \\
\text { medium-dark-gray, to medium-dark-greenish-gray siltstone and } \\
\text { phyllite, medium-gray feldspathic wacke, and grit. Purple tinge } \\
\text { common; coticules and magnetite locally abundant. }\end{array}$ & \\
\hline & Oap & $\begin{array}{l}\text { Dark-gray to grayish-black, rusty-weathering sulfidic slate and } \\
\text { phyllite interlayered with metamorphosed ultra-fine-grained, } \\
\text { sulfidic ironstone, chert, felsic tuff, and minor sandstone. Much is } \\
\text { indistinguishable from the Partridge Formation. }\end{array}$ & \\
\hline Albee Formation & OCal & $\begin{array}{l}\text { Interbedded light-gray to greenish-gray, white-weathering, } \\
\text { feldspathic, fine-grained metamorphosed sandstone and siltstone, } \\
\text { and light-gray to greenish-gray to dark-gray phyllite. Lesser } \\
\text { amounts of quartzite. Rare calc-silicate nodules. Phyllosilicates } \\
\text { commonly } 10 \text { to } 25 \text { percent of matrix. Tourmaline and magnetite } \\
\text { are sporadic accessory minerals. May be sulfidic (either pyrite or } \\
\text { pyrrhotite) and rusty weathering. Generally sharply bedded but } \\
\text { graded beds as well as slump structures are locally obvious. } \\
\text { Bedding thickness varies between less than a centimeter to more } \\
\text { than a meter. Pinstriping is common (quartzofeldspathic laminae } \\
1 \text { mm to a few millimeters thick separated by paper-thin } \\
\text { micaceous partings, commonly magnetite-bearing). }\end{array}$ & $\begin{array}{l}\text { Upper Cambrian to } \\
\text { Middle Ordovician }\end{array}$ \\
\hline Scarritt Member & OCals & $\begin{array}{l}\text { Dark-gray slate interlayered with thin beds of light-gray, fine- } \\
\text { grained, micaceous and feldspathic metamorphosed sandstone. } \\
\text { Ribby-weathering common but in places where pelite dominates, } \\
\text { bedding is difficult to identify. Abruptly graded beds less than } 1 \\
\text { cm to } 30 \mathrm{~cm} \text { thick are locally common, as is channeling and, in } \\
\text { places, soft-sediment deformation. Commonly sulfidic (either } \\
\text { pyrite or pyrrhotite) and rusty weathering. }\end{array}$ & \\
\hline
\end{tabular}


Table 1. Description of map units in the Littleton-Moosilauke area, New Hampshire.-Continued

[Map units are shown in figure 2. Abbreviations: mm, millimeter; cm, centimeter; km, kilometer]

\begin{tabular}{|c|c|c|c|}
\hline Formation & Map unit & Description & Age \\
\hline \multicolumn{4}{|c|}{ Boundary Mountains-Bronson Hill Sequence_-Continued } \\
\hline \multicolumn{4}{|l|}{ Intrusive rocks } \\
\hline \multirow{2}{*}{$\begin{array}{l}\text { Piscataquis } \\
\text { magmatic } \\
\text { belt }\end{array}$} & Dgp & $\begin{array}{l}\text { Granite and quartz monzonite, commonly intrusive into Emsian } \\
\text { strata. }\end{array}$ & $\begin{array}{l}\text { Early Devonian } \\
\text { (Emsian) }\end{array}$ \\
\hline & $\mathrm{Dm}$ & Diorite and gabbro, commonly intrusive into Emsian strata. & \\
\hline \multirow{3}{*}{$\begin{array}{l}\text { Comerford } \\
\text { Intrusive } \\
\text { Complex }\end{array}$} & & Mafic to intermediate intrusive complex. & Latest Silurian \\
\hline & Scm & $\begin{array}{l}\text { Foliated to nonfoliated, fine-grained to pegmatitic } \\
\text { metamorphosed gabbro, diorite, and tonalite; aplitic tonalite; and } \\
\text { crosscutting diabase dikes. Twenty fractions of zircon and } \\
\text { baddeleyite from three sample sites of pegmatitic phases have a } \\
\text { weighted mean }{ }^{207} \mathrm{~Pb} /{ }^{206} \mathrm{~Pb} \text { age of } 419 \pm 1 \mathrm{Ma} \text { (Rankin and others, } \\
\text { 2007). }\end{array}$ & \\
\hline & Scd & $\begin{array}{l}\text { Foliated to weakly foliated, metamorphosed tholeiitic gabbro to } \\
\text { diorite dikes. Where the dikes are abundant, sheeted dikes are } \\
\text { common. Chilled margins common. Extensive alteration with as } \\
\text { much as } 20 \text { percent calcite in some locations. Shown by overprint } \\
\text { where dikes make up roughly } 50 \text { percent of the area. }\end{array}$ & \\
\hline $\begin{array}{l}\text { Highlandcroft } \\
\text { Granodiorite }\end{array}$ & Ohi & $\begin{array}{l}\text { Foliated, medium-grained, metamorphosed granite, granodiorite, } \\
\text { and tonalite containing quartz, microcline, saussuritized } \\
\text { plagioclase, hornblende, biotite (chlorite alteration) and } \\
\text { secondary calcite and sericite. U-Pb zircon age of } 450 \pm 5 \mathrm{Ma} \\
\text { (Lyons, Aleinikoff, and Zartman, 1986). }\end{array}$ & Late Ordovician \\
\hline $\begin{array}{l}\text { Oliverian } \\
\text { Plutonic Suite }\end{array}$ & Oo & $\begin{array}{l}\text { Weakly to moderately foliated, medium-grained, commonly } \\
\text { porphyritic, biotite granodiorite. U-Pb zircon ages range from } \\
456 \pm 3 \text { to } 447 \pm 4 \text { Ma (Moench and Aleinikoff, 2003). Biotite } \\
\text { trondhjemite from the Jefferson batholith about } 8 \mathrm{~km} \text { northwest } \\
\text { of Berlin, N.H., has a U-Pb zircon age of } 454 \pm 4 \mathrm{Ma} \text {. }\end{array}$ & Late Ordovician \\
\hline $\begin{array}{l}\text { Joslin Turn } \\
\text { Tonalite }\end{array}$ & Oj & $\begin{array}{l}\text { Hypabyssal, medium-grained, weakly foliated, metamorphosed } \\
\text { biotite tonalite. Granophyric intergrowths of quartz and } \\
\text { plagioclase. U-Pb zircon age of } 469 \pm 2 \text { Ma (Moench and } \\
\text { Aleinikoff, 2003). }\end{array}$ & Middle Ordovician \\
\hline
\end{tabular}

The type localities or areas of Billings' classic six-fold Paleozoic stratigraphic section are all within 8 miles (mi) west or southwest of Exit 42 on Interstate Route 93 (I-93) at Littleton, N.H. (fig 1). All except the Clough Quartzite are in the Littleton 15-minute quadrangle. This field trip will visit roadcuts as close as possible in March to these localities. Eleven stops are planned. All exposures are at chlorite grade of Acadian (?) metamorphism and all are within the Concord, Lisbon, Littleton, and Lower Waterford 7.5-minute quadrangles. As is true for most geological fieldwork, one can learn much 
by looking carefully at the outcrop without mutilating the ledge with a hammer. We ask you to use no hammers on the ledges at Stops 5, 7, and 8. Should you be lucky enough to see any fossils, please do not remove them from Stops 5 or 7.

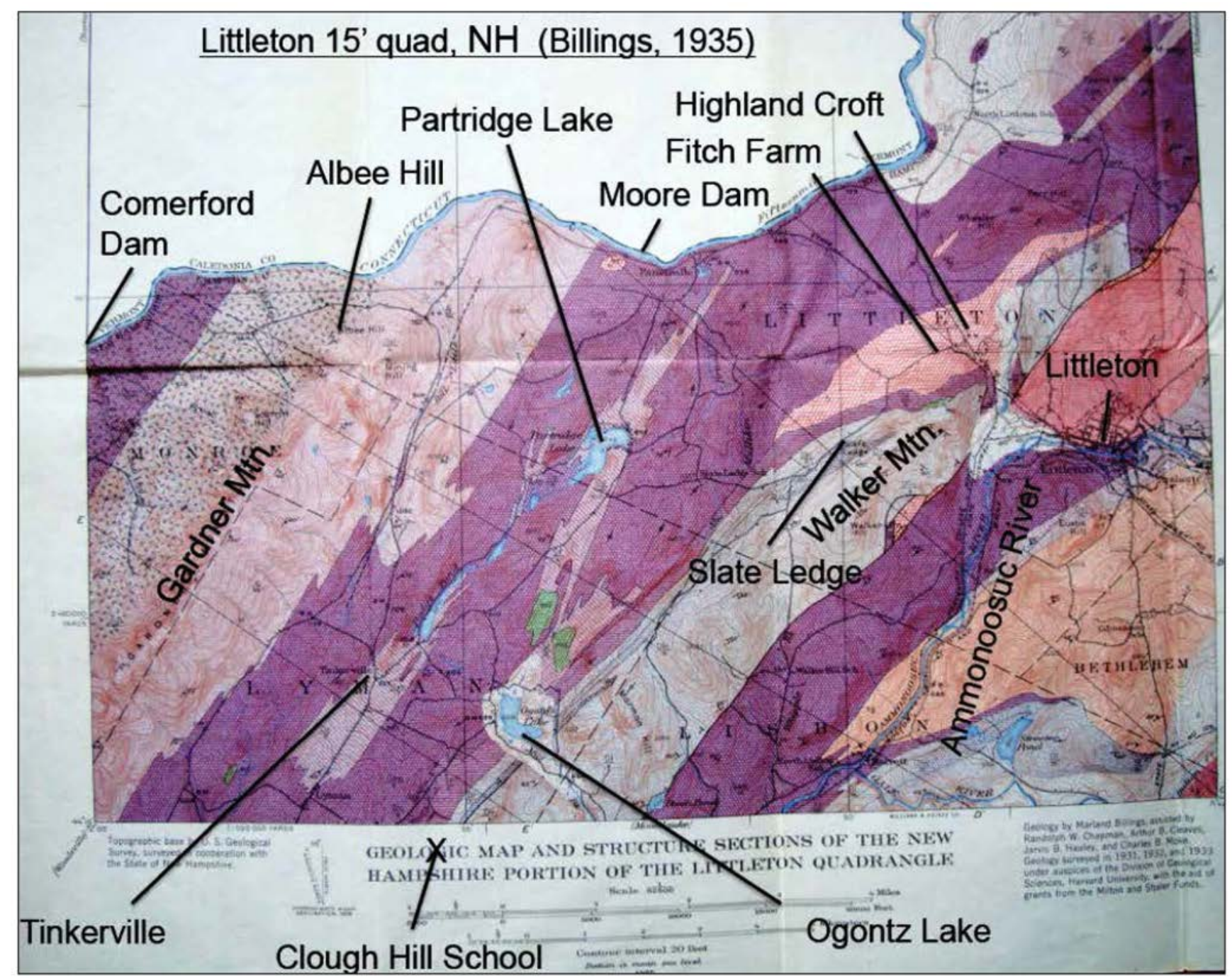

Figure 1. Geologic map of the Littleton 15-minute quadrangle, New Hampshire (Billings, 1935), locating geographic features discussed in the text.

Although the focus of this field trip is on the work Marland Billings did 80 years ago, it is legitimate to ask to what extent have his interpretations of the Littleton-Moosilauke area been subsequently modified. With the exception of the major challenge of the Piermont-Frontenac allochthon (Rankin, Tucker, and Amelin, 2013), Billings' broad conclusions remain alive and well. We have subdivided some of his stratigraphic units. We now interpret the Ammonoosuc fault to be a Mesozoic normal fault rather than a Paleozoic thrust (Thompson and Norton, 1968). The paleontologic ages of the Fitch and Littleton Formations have been refined but remain Silurian and Devonian (Harris, Hatch, and Dutro, 1983; Boucot and Arndt, 1960), including one new locality on Mount Moosilauke in the Littleton Formation at sillimanite grade (Boucot and Rumble, 1980). The ages of several plutons and stratigraphic units are constrained by isotopic dating (Lyons, Aleinikoff, and Zartman, 1986; Moench and Aleinikoff, 
2003; Rankin and others, 2007; Rankin, Tucker, and Amelin, 2013). An episode of Silurian extension has been documented (Rankin and others, 2007), based in part on a suite of mafic dikes mapped by Billings (1937) prior to the concept of sheeted dikes. Geochemical data better characterizes several units (Moss, Haskin, and Dymek, 1996; Leo, 1985, 1991; Dorais, Workman, and Aggarwal, 2008; Rankin and others, 2007; Dorais and others, 2012).

Our work in the Littleton-Moosilauke area began in 1992 as part of the team making a new bedrock geologic map of Vermont (Ratcliffe and others, 2011) and is ongoing. The geologic map (fig. 2) is taken from Ratcliffe and others (2011) and, for the geology southeast of the Ammonoosuc fault, from Rankin, Tucker, and Amelin (2013). For the field trip, a preliminary version of the geologic map of the Littleton and Lower Waterford 7.5-minute quadrangles (the southern half of the Littleton 15minute quadrangle) is one of the props (D.W. Rankin, unpub. data, 2013). This preliminary map differs in detail from that of Billings (1935). Remember, however, that we were mapping at a larger scale than was he, we spent more time in the field than did he (albeit split over about twenty 7.5-minute quadrangles), and finally, we had his maps in hand. 


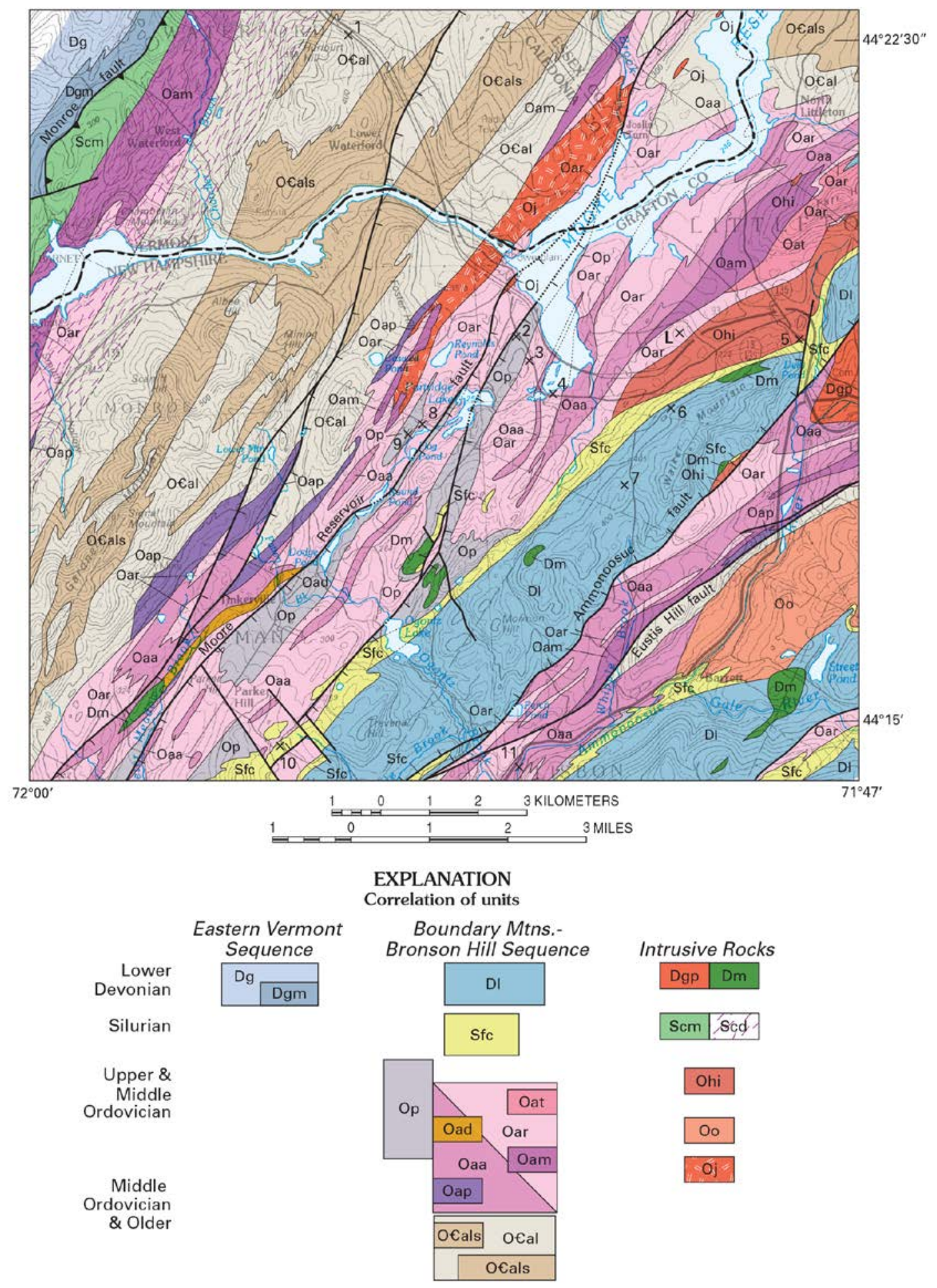

Figure 2. Geologic map of the Littleton area, New Hampshire. Map units are described in table 1. The area northwest of the Ammonoosuc fault is modified from Ratcliffe and others (2011), and the area southeast of the Ammonoosuc fault is taken from Rankin, Tucker, and Amelin (2013). The map area is within the Concord, Miles Pond, Lower Waterford, Littleton, Lisbon, and Sugar Hill 7.5-minute quadrangles (see figure 3). X indicates the location of field trip stops; $L$ is the location of the lunch stop. 
The controversy of the Piermont-Frontenac allochthon is not the focus of this trip, but neither can it be avoided. Beginning in the 1980s, Moench and coworkers challenged the interpretation of a coherent stratigraphy in the Littleton-Moosilauke area as well as in much of the upper Connecticut Valley and initiated a controversy that has persisted for more than two decades (Moench, 1990, 1992; Moench and Aleinikoff, 2003; and Moench and others, 1987, 1995). They proposed that much of the section mapped as pre-Middle Ordovician Albee Formation of Billings (1937) was, instead, a thick, largely turbiditic Silurian sequence similar to what Moench (1971) had defined in the Rangeley area, Maine. The Silurian Rangeley sequence mapped by Moench and coworkers in the upper Connecticut Valley was hypothesized to constitute a 200-kilometer (km)-long Piermont-Frontenac allochthon transported westward in the latest Silurian to Early Devonian as a soft-sediment gravity slide on a hypothesized Foster Hill sole-fault.

We will not visit outcrops that shed light on this argument during this field trip, but we are sure the discussion will arise. Our mapping plus new uranium-lead (U-Pb) zircon ages by Tucker and Amelin cannot be reconciled with the existence of a large gravity-slide allochthon, although we confirm a much smaller ( $\left.25-\mathrm{km}^{2}\right)$ allochthon of Rangeley-like Silurian (?) turbidites near Piermont, N.H., about 45 km south-southwest of Littleton, which was emplaced by post-nappe-stage hard-rock thrusting. These arguments are laid out in Rankin, Tucker, and Amelin (2013), which you may want to look at before the field trip.

\section{Geologic Setting}

The geologic setting is summarized from Rankin, Tucker, and Amelin (2013), wherein are extensive references to the supporting literature. Most of the Littleton-Moosilauke area is within the composite Boundary Mountains-Bronson Hill anticlinorium, a post-Early Devonian structure, which consists of Cambrian to Lower Devonian strata. It is the locus of the Middle Ordovician to earliest Silurian Bronson Hill magmatic arc (Ammonoosuc Volcanics, Partridge Formation, and Oliverian Plutonic Suite) that extends from Maine down the eastern side of the Connecticut River to Long Island Sound (for example, Hibbard and others, 2006). The deformed and partly eroded arc is locally overlain by a relatively thin Silurian section (Clough Quartzite and Fitch Formation) that thickens markedly eastward across a syn-sedimentary tectonic hinge line (east of the Littleton area) to as much as $5 \mathrm{~km}$ in the Central Maine trough (Rangeley sequence). The Silurian section near Littleton is disconformably overlain by a thicker Lower Devonian section that includes volcanic rocks (Littleton Formation).

The pre-Middle Ordovician rocks were probably deformed by the pre-Middle Ordovician Penobscottian orogeny and all the pre-Silurian rocks by the Late Ordovician Taconian orogeny. In the Littleton-Moosilauke area Billings $(1935,1937)$ recognized a series Acadian folds. From northwest to southeast, they are the Gardner Mountain anticline (more of an arch, with Albee Formation flanked by Ammonoosuc Volcanics; Billings also refers to it as an arch), Walker Mountain syncline, Salmon Hole Brook syncline, Garnet Hill syncline, and Bronson Hill anticline. Billings (1956) suggested that the Gardner Mountain anticline is the southwestern extension of a broader regional structure, the Coos anticlinorium, which was better defined and renamed the Boundary Mountain (sic) anticlinorium by Albee (1961). Billings also recognized the increasing structural complexity to the southeast and renamed the Bronson Hill an anticlinorium.

South of Littleton, the Bronson Hill anticlinorium (southeast of the Ammonoosuc River in figure 2) is characterized by mantled gneiss domes consisting of 456- to 442-Ma core gneisses of probable intrusive igneous origin, overlain by a cover sequence consisting of Ammonoosuc Volcanics to Littleton Formation. The core gneisses are grouped into the Oliverian Plutonic Suite. The formation of the gneiss domes, perhaps due to the gravitational rise of the Oliverian cores, was preceded by the 
formation of Alpine-scale west-directed fold and thrust nappes involving Emsian and older strata. The timing of pulses of deformation and metamorphism to the south is complex and extends into the late Paleozoic.

A number of Mesozoic normal faults, the most prominent of which is the west-dipping Ammonoosuc fault, also cuts the Boundary Mountains-Bronson Hill anticlinorium. Near Piermont, N.H., it juxtaposes kyanite-grade rocks on the east against chlorite-grade rocks on the west. The amount of displacement decreases to the northeast into north-central New Hampshire.

The composite Boundary Mountains-Bronson Hill sequence is separated from the Silurian and Devonian rocks of the Eastern Vermont sequence to the west by the Monroe fault, interpreted to be a west-directed, steeply dipping late Acadian thrust fault.

\section{Road Log}

\section{Cumulative Mileage and Stop Descriptions}

0.0 Front door, Mount Washington House.

0.6 Turn right onto U.S. Route 302 westbound.

14.3 Bethlehem town center. An ancient sign in the middle of town states that Bethlehem is the highest town east of the Rocky Mountains. Bethlehem's elevation is about 1,475 feet (ft), which may make it the highest town in New England, but the statement overlooks many towns at higher elevations farther south in the Appalachians and in the Great Plains.

17.5 Bear right onto I-93 northbound at Exit 40.

19.0 Pass Exit 41, East Littleton.

Littleton 7.5-minute quadrangle. The field trip stops are indicated in figures 2 and 3. 


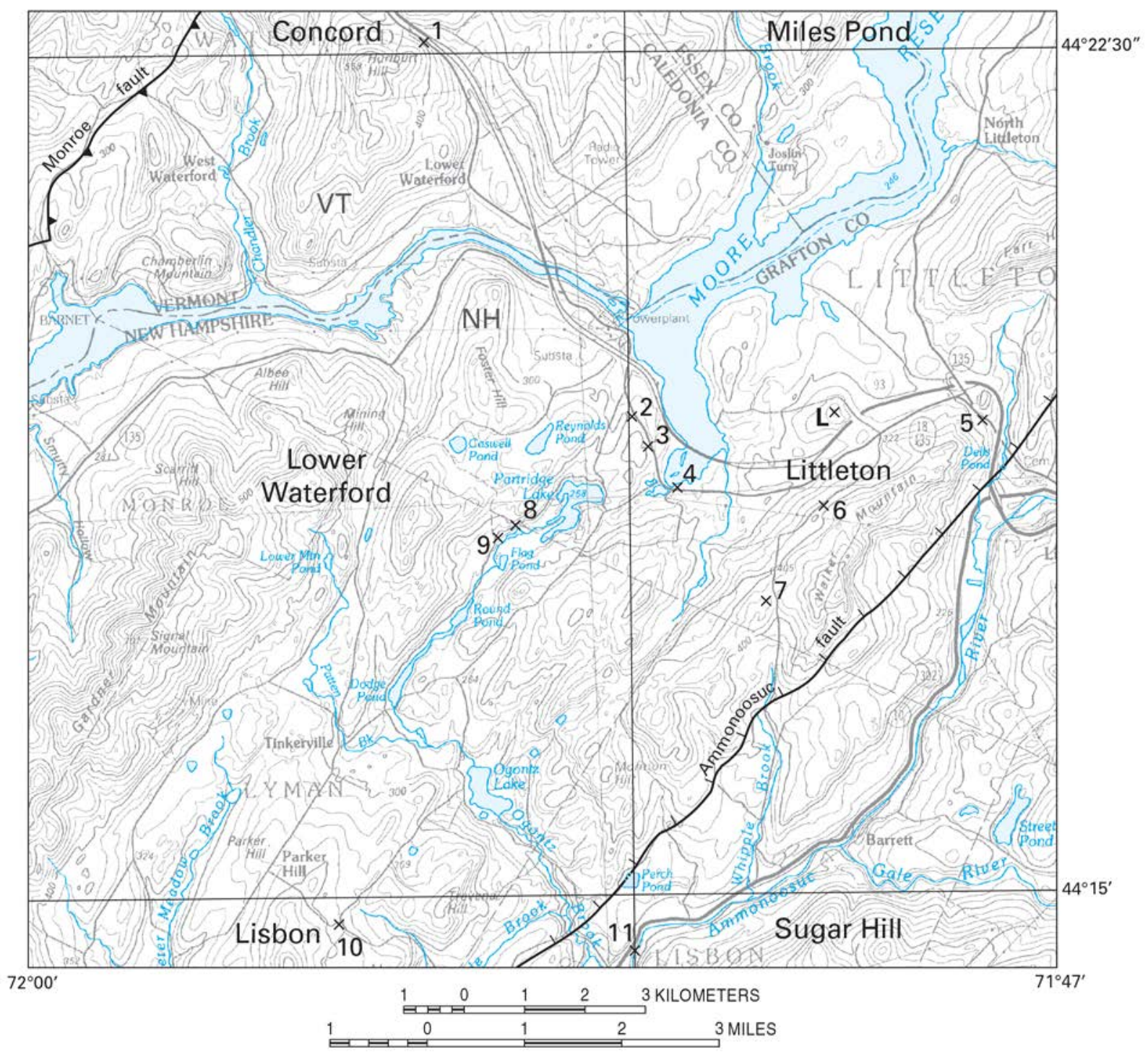

Figure 3. Topographic map of the Littleton area, New Hampshire. Names and boundaries of 7.5-minute quadrangles are shown. Field trip stops are numbered and indicated by $\mathrm{X}$; lunch stop location is indicated by L.

21.0-21.2 Amphibolite, Ammonoosuc Volcanics (unit Oaa).

22.7 Pass Exit 42, West Littleton and U.S. 302.

23.4 The nonconformity between the Highlandcroft Granodiorite (Oh) and the Fitch Formation (Sf) is exposed at the south end of the roadcut (left).

23.9 Pass Exit 43; Highlandcroft Granodiorite roadcuts on both sides of exit. This location is Stop A2 of New England Intercollegiate Geological Conference (NEIGC) 1996 field trip (Rankin, 1996).

25.1 Roadcut on right; Highlandcroft Granodiorite. 
26.1-26.4 Long roadcut, Ammonoosuc Volcanics. Rhyolite at east end followed by a thick section of hornblende andesite. A Mesozoic mafic dike is exposed on both sides of the road.

27.4 Moore Reservoir causeway. On far (west) side of causeway, a long series of ledges some distance to the left of the Interstate consist of rhyolite of the Ammonoosuc Volcanics (Oar).

27.7 White-weathering silicified rhyolite (Oar).

$27.9 \quad$ Partridge Formation (Op).

28.3 Bear right on Exit 44 through roadcuts of Oar.

28.6 Turn left onto N.H. Route 18/135 and pass Moore Dam, now owned by TransCanada. The dam opened in 1957, has a height of $178 \mathrm{ft}$, and backs up a reservoir of 3,490 acres.

Cross the unexposed hypabyssal Joslin Turn Tonalite. It is exposed in a small outcrop along I-93, and Billings (1935) mapped a small body of plutonic rock here that he called Highlandcroft Granodiorite. Moench and Aleinikoff (2003) reported a U-Pb zircon age of 469 $\pm 2 \mathrm{Ma}$ for the Joslin Turn from the more extensive part of the pluton in adjacent Vermont (Eric and Dennis, 1958). Moench and Aleinikoff (2003) interpreted the Joslin Turn to be intrusive into the Ammonoosuc Volcanics, as do we. This surprisingly old age for the Joslin Turn greatly complicates the internal stratigraphy and provenance of the Ammonoosuc. Moench and Aleinikoff (2003) also reported a U-Pb zircon age of $443 \pm 4 \mathrm{Ma}$ for rhyolite tuff breccia of the Ammonoosuc from Bath, N.H., east of the Ammonoosuc fault along the Ammonoosuc River. We will return to this topic later.

\section{Lower Waterford 7.5-minute quadrangle.}

$29.4 \quad$ Bear right on N.H. 18.

29.6 Cross Connecticut River into Vermont on Vt. Route 18.

30.7 Village of Lower Waterford and home of upscale Rabbit Hill Inn.

\section{Concord 7.5-minute quadrangle.}

Roadcut on left is Stop 1. Tight parking on right or at turnaround ahead.

\section{Stop 1. Albee Formation (O€al)}

Billings (1935) proposed the name Albee for slates and quartzites exposed on Gardner Mountain, which is in New Hampshire southwest of us. He designated the type locality as that part of Gardner Mountain between Hunt Mountain (Barnet quadrangle) and Albee Hill (Lower Waterford quadrangle) (fig. 1). Unfortunately, in March, there is no easy road access to outcrops of the Albee Formation in the type area.

The Albee Formation here is interlayered light-gray, fine-grained feldspathic, noncalcareous sandstone and greenish-gray to dark-gray pelite, some sulfidic. Much of the sandstone is pinstriped. In places one can see layering transposed into a steeply southeast-dipping foliation. 


\section{Lower Waterford 7.5-minute quadrangle.}

36.7 Junction with N.H. 135 just after crossing Connecticut River back into New Hampshire. Turn left onto N.H. 18/135.

\section{Littleton 7.5-minute quadrangle.}

37.5 Pass entrance (northbound) to I-93 (Exit 44) and continue on N.H. 18/135.

Roadcut east of the I-93 entrance is brecciated Highlandcroft Granodiorite interpreted to be in the hanging wall of an east-dipping Mesozoic (?) Moore Reservoir fault (fig. 2). As an alternative viewpoint, Moench (1999, Stop 5) described this as interfingering of Joslin Turn Tonalite and Ammonoosuc Volcanics. Thin sections show no granophyric texture (a trademark of Joslin Turn) and no interfingering rhyolite, but much shearing and brecciation.

Pass under I-93 and pass entrance, left, to rest area (closed for the season).

\section{Stop 2. Sulfidic black slate, Partridge Formation (Op)}

Billings (1935) designated nearby Partridge Lake, about one mile on strike to the southsouthwest, as the type locality. There are no outcrops of the Partridge on Partridge Lake that are easily accessible to us today. This is typical graphitic, rusty weathering "cruddy black slate" (CBS) of the Partridge. As Billings noted, cleavage is conspicuous, but bedding is rarely observed. A revisit to this outcrop in August 2013 showed that bedding is faintly visible (N. 10 $10^{\circ}$ E. $70^{\circ}$ E.) The dominant cleavage bears $\mathrm{N} .10^{\circ} \mathrm{E} .-70^{\circ} \mathrm{W}$. The intersection of this with a second cleavage $\left(\mathrm{N}\right.$. $40^{\circ} \mathrm{E} .-75^{\circ} \mathrm{W}$.) produces a penciling that bears $\mathrm{N} .95^{\circ} \mathrm{W}$. and plunges $70^{\circ} \mathrm{W}$. The sulfide is too fine grained to resolve, but at this low metamorphic grade, it is probably pyrite.

Billings mapped the Partridge as overlying the Ammonoosuc Volcanics and underlying the Clough Quartzite. That is clearly true for much of the Partridge. We are convinced, however, that deposition of black slate also overlapped in time with the Ammonoosuc Volcanics. We will discuss this further at Stops 8 and 9.

Continue south on N.H. 18/135 to mile 38.7. This is Stop 3.

\section{Stop 3. Rhyolite tuff-breccia, Ammonoosuc Volcanics (Oar)}

Billings (1935) proposed the name Ammonoosuc Volcanics for volcanic rocks that overlie the Albee Formation and underlie the Partridge Formation. He designated the type area as the region bounded by Slate Ledge School (intersection of Gannon and Slate Ledge Roads, Littleton quadrangle), Partridge Lake, Ogontz Lake, and Tinkerville (all in the Lower Waterford quadrangle) (fig. 1). Billings took the name from the Ammonoosuc River, which flows south from Littleton a few miles to the southeast. He notes that the Ammonoosuc Volcanics is well exposed along the river, but is of higher 
metamorphic grade. The rhyolite here at Stop 3 is about half a mile north of the type area and is interpreted to be continuous in the subsurface with the type area.

The Ammonoosuc is a complex unit of interlayered and interfingering volcanic and volcaniclastic rocks, pelite, siltstone, and ironstone (table 1); compositions range from basalt to rhyolite. We have attempted to map rock types within the Ammonoosuc. These are generalized subdivisions representing a dominant rock type but commonly containing interlayers of the other lithologies. Unfortunately there are no viable roadside outcrops of unit Oaa (mafic to intermediate volcanic rocks) of low metamorphic grade along our field trip route. Unit Oaa is spectacularly exposed along I-93 on the long hill up from the east side of Moore Reservoir (mile 26 in this road log). A stop there is not possible.

The rocks in the roadcut at Stop 3 are strongly foliated (N. $25^{\circ}$ E. $\left.-75^{\circ} \mathrm{W}\right)$. Note the waxy luster on the foliation surfaces. One's first impression of the rock is that it is a foliated but homogeneous aphanitic rhyolite containing scattered feldspar crystals, some as large as 1 centimeter $(\mathrm{cm})$ across. In a few places in the roadcut one can see that much of the rock is fragmental, that is, a tuff breccia. This can be much better seen if one walks up to the relatively smooth top surface of the ledge. Most of the lithic clasts are quartz- and feldspar-phyric rhyolite. What is the age of this part of the Ammonoosuc? Because it is interpreted to underlie the immediately adjacent outcrop of Partridge (Stop 2), it could well belong to the younger, 450-Ma, Ammonoosuc. On the other hand, this belt of unit Oar traces north across Moore Reservoir where it overlies the Ordovician-Cambrian Albee Formation near the Joslin Turn Tonalite (fig. 1 and farther northeast). It could be older than 469 Ma. We need more isotopic ages.

Continue across causeway over Moore Reservoir on N.H. 18/135 to mile 39.1, which is Stop 4.

\section{Stop 4. Rhyolite, Ammonoosuc Volcanics (Oar)}

The roadcut, left, is homogeneous-appearing, aphanitic, “porphyritic”, light-bluish-gray rhyolite. Again, this roadcut is about half a mile north of and on strike with rhyolite outcrops in the type area. Again, note the waxy luster on the foliation surfaces. The rhyolite contains about 10 percent phenocrysts of plagioclase and quartz in a ratio of about 4:1. The plagioclase is as large as 2 millimeters (mm), twinned, non-zoned, and some is glomerophyric; other crystals are broken. The quartz is rarely as large as $1 \mathrm{~mm}$ and some crystals are embayed. On the basis of one thin section the crystals have a large range in size and are unevenly distributed. The rhyolite is probably a crystal-lithic tuff, although rock fragments are not obvious in this non-weathered outcrop. Secondary minerals in the matrix/groundmass include sericite, epidote, and calcite; opaque minerals are rare. An analysis of the rhyolite normalized, volatile-free and with iron reduced shows 74.48 weight percent $\mathrm{SiO}_{2}$. A sample collected for $\mathrm{U}-\mathrm{Pb}$ analysis was barren of zircons, although the rhyolite contains 153 ppm Zr.

Continue east on N.H. 18/135.

41.2 Entrance to Littleton Regional Hospital, our lunch site, and roadcut of Highlandcroft Granodiorite.

42.0 Site of the former G.E. Fitch Farm, left, from which the name Fitch Formation is taken. Parts of the collapsed barn remain. Billings (1935) designated the farm as the type locality of the Fitch, which crops out on the ridge to the right about $200 \mathrm{ft}$ vertically above the road. Silurian fossils have been known from that locality for 131 years (Hitchcock, 1874) and most recently were examined by 
Harris, Hatch, and Dutro (1983). Conodonts date the Fitch here as no older than latest Ludlovian and at least as young as early Pridolian.

42.3 T-intersection. Turn right on the continuation of N.H. 18. Type locality of Highlandcroft Granodiorite is the knob on the far side of the intersection. Until about two years ago a barn stood on the knob with "Highland Croft" painted on its front in large white letters.

\section{Stop 5. Fitch Formation}

NO HAMMERS PLEASE AT THIS ROADCUT. Also, please do not remove fossils.

Billings (1935) proposed the name Fitch Formation for limestones and related sedimentary rocks of "middle" Silurian age in the Littleton area. Fitch ledges extend about 70 meters (m) along the road. The southeast part of the section consists of purplish-weathering, dark-gray calcareous metasiltstone and phyllite. The siltstone contains calcite segregations and veins. Pyrite cubes weather out to leave 2- to 5-mm holes. Foliation is parallel to bedding (N. $45^{\circ}$ E. $-85^{\circ}$ E.) and both are folded about an axis that plunges $25^{\circ}$ to the southwest. In the middle of the section along the road is a disturbed zone and moderately east-dipping fault, thought to be an antithetic offshoot of the Ammonoosuc fault, which is only about $600 \mathrm{~m}$ to the southeast. The slip surface is N. $50^{\circ} \mathrm{E}$. $-65^{\circ} \mathrm{E}$. In this roadcut, the footwall of the fault includes, east to west, brecciated Highlandcroft Granodiorite followed by $2 \mathrm{~m}$ of bedded (N. $20^{\circ}$ E. $-75^{\circ} \mathrm{W}$.) limestone conglomerate (silty matrix) containing Highlandcroft clasts. Possibly the brecciated Highlandcroft-conglomeratic Fitch contact represents the Highlandcroft-Fitch nonconformity that is also exposed along I-93 about $500 \mathrm{~m}$ to the north. The limestone conglomerate is succeeded to the northwest by $35 \mathrm{~m}$ of calcareous siltstone and the covered contact with the main Highlandcroft pluton.

43.0 Dell Road; turn around.

45.8 Littleton Regional Hospital. LUNCH.

Exit hospital and turn left onto N.H. 18/135.

45.9 Turn right on Slate Ledge Road. Cross the unexposed belt of the Fitch Formation.

46.8 Park on "grass" near driveway on left and walk a short distance along the road to Slate Ledge Quarry (abandoned). We have the landowner's permission to enter the quarry at our own risk. Enroute to the quarry we will pass scrappy ledges obscured by vegetation. We made a feeble attempt to clear these in September 2012. In 1997 toward the eastern end of the exposures, we observed graded beds ( $\mathrm{N} .50^{\circ} \mathrm{E} .-50^{\circ} \mathrm{S}$.), topping east cut by cleavage (N. $70^{\circ} \mathrm{E} .-75^{\circ} \mathrm{S}$.). Toward the western end of the exposures are tight, low-amplitude z-folds with axes N. $25^{\circ} \mathrm{E}$. plunging $65^{\circ} \mathrm{W}$. Cleavage $\left(\mathrm{N} .70^{\circ} \mathrm{E} .-75^{\circ} \mathrm{S}\right.$.) in fold noses is axial planar to the folds.

\section{Stop 6. Pelitic facies of the Littleton Formation (DI)}

Billings (1935) modified the name Littleton argillite of Ross (1923) to Littleton Formation for slates, sandstones, and volcanic rocks in Littleton Township. He designated the type locality as around 
Slate Ledge, Walker Mountain, and the district lying a mile southwest. For many geologists, Slate Ledge Quarry has become the effective type locality, which overemphasizes the pelitic nature of the formation. The quarry is stratigraphically in the lower part of the Littleton, immediately beneath a persistent zone of felsic volcanic rocks and an unknown distance above the unexposed Fitch contact.

Conditions in the quarry have deteriorated over the years. The narrow entrance is hazardous. Loose rocks above could tumble down. Lichens and weathering obscure bedding and textures. We may decide not to gamble on entering the quarry and if we do enter, do not tarry in the entrance slot. Should we not enter the quarry, the spoil pile from the quarry is a short distance downhill across Slate Ledge Road. We are welcome to visit it.

Most of the quarry appears to consist of dark-gray slate. Sharp eyes may see thin graded beds with thin sandy or silty bottoms. Thin, pelitic turbidites probably make up a lot of the quarry. Numerous sandy bottoms are calcareous. Billings did not mention the calcareous bottoms, but did note the presence of diopside-clinozoisite-amphibole concretions in the high-grade Littleton. In thin section the slate contains tiny porphyroblasts of chlorite. Note the presence of fairly abundant pyrite, commonly in large cubes that are particularly abundant in the sandy bottoms of the turbidites. At higher metamorphic grade, where the iron sulfide is pyrrhotite, weathered Littleton is quite rusty and difficult to distinguish from the Partridge Formation.

Bedding (N. $45^{\circ}$ E. $-85^{\circ}$ E.) tops to the southeast. Cleavage dips southeast more gently than the bedding ( $\mathrm{N} .75^{\circ} \mathrm{E} .-75^{\circ} \mathrm{E}$.), an observation also made on the roadside ledges we passed on the way to the quarry. The implied synformal axis to the northwest is hard to reconcile with the Walker Mountain syncline.

Continue southwest on Slate Ledge Road. Ledges, left, on the slope under the powerline are rhyolite conglomerate, breccia, and undivided volcanic rocks that constitute a mappable unit, including mafic volcanic rocks, in the lower part of the Littleton Formation in both the Walker Mountain and Salmon Hole Brook synclines. Some rhyolite conglomerates are matrix supported (dark-gray slate).

47.6 Bear left, uphill on Walker Hill Road.

48.2 Crest of Walker Mountain. Turn right on Grandview Road.

48.3 Beginning of loop road. Bear right and park on right side of road. This is Stop 7.

\section{Stop 7. Sandy facies of the Littleton Formation (DI)}

Years ago we found fossil fragments in a float block of sandstone below the outcrop. Fossils were first discovered in the Littleton near the height-of-land on Walker Hill Road by Lahee (1912). Billings and Cleaves (1934) made more extensive collections from here and elsewhere on Walker Mountain and concluded an Oriskany (Pragian) age. Boucot in Boucot and Arndt (1960) re-examined these collections, made additional collections to the northeast on Dalton Mountain, and established an Emsian age for the type Littleton. Brachiopods from Beaver Brook suggest a slightly older age (Pragian) for the sillimanite-grade Littleton of the Moosilauke septum (Boucot and Rumble, 1980).

Regionally, as well as here on Walker Mountain, the Littleton becomes sandier higher in the section (Lyons and others, 1997). Most of this exposure is fine-grained feldspathic metasandstone with dark slate partings. Dark-gray slate is more prominent toward the road junction. Foliation is N. $40^{\circ}$ E.$75^{\circ} \mathrm{W}$. Pyrite is abundant in cubes as large as $0.5 \mathrm{~cm}$ and commonly with quartz fibers growing in the 
pressure shadows. This is typical of the Littleton in the Walker Mountain syncline. No one has studied these. NO HAMMERS, PLEASE. Also, please do not remove fossils.

Continue around loop road (1.5 mi), return on Grandview Road, bear left on Walker Hill Road, and bear right on Slate Ledge Road.

$52.1 \quad$ Turn left onto N.H. 18/135.

54.4 Pass site of Stop 4 at east end of Moore Reservoir causeway.

54.6 Turn left on Partridge Lake Road at west end of Moore Reservoir causeway.

\section{Lower Waterford 7.5-minute quadrangle.}

55.3 Follow Partridge Lake Road around sharp right turn. Approximate unexposed contact between Ammonoosuc Volcanics (east) and overlying Partridge Formation (west).

55.4 Partridge Lake. Bear right and follow the narrow, twisting Partridge Lake Road around Partridge Lake.

55.6 Cross the unexposed Mesozoic (?) normal (down to the east) Ogontz fault: Oar west, Op east).

55.8-56.2 The road follow follows the Moore Reservoir fault, another Mesozoic normal fault, which is down to the east and mostly unexposed: Oar west and Op east. This is the same fault that we crossed at Exit 44 of I-93 (mile 37.5). This fault is probably a reactivated Paleozoic fault.

56.5 Road becomes Pond Road. Park in large open area just north of the Littleton-Lyman town line. This is Stop 8.

\section{Stop 8. Rhyolite/mudstone debris flow interlayered with rhyolite aphanitic tuff and black slate} (Oar)

This exposure represents a transition zone between units Oap and Oar of the Ammonoosuc Volcanics. NO HAMMERS, PLEASE. The riprap below the guardrail east of the road offers abundant hand samples.

Most of the roadcut consists of laminated and bedded, tightly folded debris-flow material (“diamictite”) consisting of dark, tuffaceous pelite containing abundant clasts of light-gray tuff from vanishingly small pieces to interbeds of aphyric tuff several centimeters thick and less abundant black slate chips from vanishingly small pieces to interbeds of black slate. The diamictite also contains scattered feldspar and glassy quartz xenocrysts as well as less-deformed clasts of quartz-phyric and (or) feldspar-phyric rhyolite. Clearly volcanism was contemporaneous with the deposition of black mud. Light-colored, slightly rusty weathering dolostone lenses are sparingly present. At the north end of the roadcut, isoclinal dextral folds of bedding $\left(\mathrm{N} .25^{\circ} \mathrm{E} .-80^{\circ} \mathrm{W}\right.$.) plunge $70^{\circ}$ to the southwest. Foliation is axial planar to the folds. The intersection of a poorly developed second foliation (N. $90^{\circ}$ E. $-70^{\circ}$ E. ) with the regional foliation produces a penciling in the pelite and tuff and a pronounced lineation in the tuff.

When this roadcut was fresh in the year 2000, an 8-cm-thick bed of sideritic ironstone was exposed at the gentle curve concave-northwest about $450 \mathrm{ft}$ south of the town line. Several thinner 
layers of the punky-weathering ironstone were also visible between here and the sharper road curve to the southwest.

56.65 Sharp curve to right. Strongly foliated and lineated rhyolite crystal (plagioclase) tuff of Oar.

56.7 Park on right side of road opposite sharp ridge on left. This is Stop 9.

\section{Stop 9. Sulfidic black slate, Ammonoosuc Volcanics (Oap)}

This is the eastern edge of a 2.4- by 0.3-km (maximum dimensions) lens of sulfidic, dark-gray slate ("cruddy black slate," CBS) that lies west of the debris flow of the last stop. The slate is bounded on the west by felsic Ammonoosuc. We mapped the lens as a pelite unit, Oap, of the Ammonoosuc Volcanics but the rock is indistinguishable from the Partridge; the lens is shown incorrectly in figure 2 as Op.

Continue south on Pond Road.

57.7 Ledges of rhyolite of the Ammonoosuc on right behind gravel pit.

The road along Dodge Pond is interpreted to be in the Partridge Formation immediately southeast of the Moore Reservoir fault. One may legitimately ask: Why Partridge and not unit Oap of the Ammonoosuc?

59.0 Turn left on Lyman Road (paved).

59.05 Outcrop on right; Partridge Formation.

No roadside exposure for the next 1.3 miles but we cross various units of the Ammonoosuc Volcanics.

60.2 Cross position of the Ogontz fault: Oar on west, Op on east.

60.3 Turn right on gravel Quebec Road (Stickney Road on topo sheet). Unexposed Fitch Formation.

The long uphill stretch of Quebec Road is mostly in the Fitch, with lenses of Clough conglomerate against the Ogontz fault.

$61.5 \quad$ Crest of hill.

\section{Lisbon 7.5-minute quadrangle.}

Quebec Road dead-ends at Clough Hill Road (Parker Hill Road on topo sheet). This is Stop 10.

\section{Stop 10. Clough Quartzite and Fitch Formation}

Billings (1935) proposed the name Clough Conglomerate for interbedded quartz conglomerate and quartzite that directly underlies the Fitch Formation. He (Billings, 1955, 1956) changed the name to Clough Quartzite to better reflect the dominant lithology. Billings does not designate a type locality, but takes the name Clough from the Clough Hill district, which is essentially where we are (figs. 1 and 2). 
This outcrop is a large, magnificent, mostly pavement exposure of conglomeratic Clough Quartzite. The conglomerate is both clast-supported and matrix-supported and is poorly sorted. The clasts range in size to as much as 5 by $7 \mathrm{~cm}$. They are mostly vein quartz but include gray slate and magnetite-bearing ironstone. We saw no granite clasts. Where clast-supported, the quartz clasts indent one another but otherwise are little deformed. Bedding is crude but a couple of graded beds (N. $40^{\circ}$ E.$80^{\circ} \mathrm{E}$.) top to the east. Rhyolite followed by greenstone of the Ammonoosuc is exposed around the corner on Clough Hill Road to the west.

Walk east along Clough Hill Road $30 \mathrm{~m}$ or so. Calcareous siltstone of the Fitch Formation is exposed under the powerline. Bedding is N. $45^{\circ}$ E. $-85^{\circ}$ E.; foliation N. $65^{\circ}$ E. $-85^{\circ}$ N. We are on the slightly overturned limb of the Walker Mountain Syncline a little more than $10 \mathrm{~km}$ southwest of Slate Ledge quarry.

Continue downhill to the southeast on Clough Hill Road. Roadcuts are absent for the next mile, but mapping shows that the section from Ammonoosuc to Fitch is repeated by faulting.

Exposure on right of the Littleton Formation. The repeated, unexposed Silurian section has an across-strike breadth of only $100 \mathrm{~m}$.

64.1 Turn left on Cole Plain Road just after crossing the unexposed Mesozoic, west-dipping Ammonoosuc normal fault. Here the Littleton Formation of the Walker Mountain syncline (west) is downdropped against the Albee Formation (east).

64.6 The low ridge to the left is held up by the Fitch Formation and Clough Quartzite exposed in a fault slice along the Ammonoosuc fault.

65.5 Cole Plain Road dead-ends into Lyman Road. Turn right on Lyman Road. The waterfall across from the intersection is held up by chlorite-grade Littleton Formation in the footwall of the Ammonoosuc fault. The fault (N. $65^{\circ} \mathrm{E} ., 40^{\circ} \mathrm{W}$.) is exposed in the streambed and near the gorge wall. Slickenlines trend $\mathrm{N} .80^{\circ} \mathrm{W}$. and plunge $30^{\circ} \mathrm{W}$. Strongly sheared rhyolite tuff (Oar) of the Ammonoosuc Volcanics forms the footwall. Access to the exposure is treacherous.

65.8 Lyman Road dead-ends into U.S. 302. Turn left on U.S. 302.

66.4 Roadcut on left. Park on shoulder on right. This is Stop 11. WATCH OUT FOR TRAFFIC.

\section{Stop 11 (optional). Ammonoosuc Volcanics}

Long roadcut exposing amphibolite (Oaa) interlayered with lesser amounts of metamorphosed rhyolite (not mapped separately) of the Ammonoosuc Volcanics. This is planned as a quick stop to look at mafic rocks of the Ammonoosuc (Oaa) at intermediate-grade, probably garnet, metamorphism east of the Ammonoosuc fault. An analysis of the amphibolite normalized, volatile-free and with iron reduced shows 49.21 weight-percent $\mathrm{SiO}_{2}$.

Turn around and head south on U.S. 302. Cross the Ammonoosuc River immediately south of Lyman Road. Turn left on N.H. 117 toward Sugar Hill. The highway follows the valley of Salmon Hole Brook. 


\section{Sugar Hill 7.5-minute quadrangle.}

Rocks exposed in Salmon Hole Brook between here and mile 67.4 include several rock types of the Ammonoosuc Volcanics as well as Partridge Formation, Clough Quartzite, and Littleton Formation of the Salmon Hole Brook syncline. The Fitch Formation does not crop out in this section along the brook.

68.4

Roadcut on left of Littleton Formation containing medium-size staurolite and small garnet porphyroblasts.

\section{End of road log.}

Return to Bretton Woods via Sugar Hill (spectacular views of the White Mountains), Franconia, I-93, and U.S. 3.

\section{References Cited}

Albee, A.L., 1961, Boundary Mountain anticlinorium, west-central Maine and northwestern New Hampshire: U.S. Geological Survey Professional Paper 424-C, p. C51-C54.

Billings, M.P., 1928, The petrology of the North Conway quadrangle in the White Mountains of New Hampshire: American Academy of Arts and Sciences, v. 63, no. 3, p. 66-137.

Billings, M.P., 1934, Paleozoic age of the rocks of central New Hampshire: Science, v. 79, p. 55-56. Billings, M.P., 1935, Geology of the Littleton and Moosilauke quadrangles, New Hampshire: Concord, N.H., New Hampshire State Planning and Development Commission, 51 p., includes geologic map, scale 1:62,500.

Billings, M.P., 1937, Regional metamorphism of the Littleton-Moosilauke area, New Hampshire: Geological Society of America Bulletin, v. 48, no. 4, p. 463-566.

Billings, M.P., comp., 1955, Geologic map of New Hampshire: Washington, D.C., U.S. Geological Survey, 1 sheet, scale 1:250,000.

Billings, M.P., 1956, The geology of New Hampshire. Part II - Bedrock geology: Concord, New Hampshire Planning and Development Commission, 203 p., scale 1:250,000.

Billings, M.P., and Cleaves, A.B., 1934, Paleontology of the Littleton area, New Hampshire: American Journal of Science, v. 28, p. 412-438.

Boucot, A.J., and Arndt, R., 1960, Fossils of the Littleton Formation (Lower Devonian) of New Hampshire: U.S. Geological Survey Professional Paper 334-B, p. 41-51.

Boucot, A.J., and Rumble, D., III, 1980, Regionally metamorphosed (high sillimanite zone, granulite facies) Early Devonian brachiopods from the Littleton Formation of New Hampshire: Journal of Paleontology, v. 54, p. 188-195.

Dorais, M.J., Workman, J., and Aggarwal, J., 2008, The petrogenesis of the Highlandcroft and Oliverian Plutonic Suites, New Hampshire; implications for the structure of the Bronson Hill terrane: American Journal of Science, v. 308, p. 73-99.

Dorais, M.J., Atkinson, M., Kim, Jon, West, D.P., and Kirby, G.A., 2012, Where is the Iapetus suture in northern New England? A study of the Ammonoosuc Volcanics, Bronson Hill terrane, New Hampshire: Canadian Journal of Earth Science, v. 49, p. 189-205.

Eric, J.H., and Dennis, J.G., 1958, Geology of the Concord-Waterford area, Vermont: Vermont Geological Survey Bulletin 11, 66 p.

Harris, A.G., Hatch, N.L., Jr., and Dutro, J.T., Jr., 1983, Late Silurian conodonts update the metamorphosed Fitch Formation, Littleton area, New Hampshire: American Journal of Science, v. 283, p. 722-738. 
Hibbard, J.P., van Staal, C.R., Rankin, D.W., and Williams, H., 2006, Lithotectonic map of the Appalachian orogen, Canada-United States of America: Geological Survey of Canada Map 2096A, scale 1:1,500,000, Sheet 2, North Sheet.

Hitchcock, C.H., 1874, On Helderberg corals in New Hampshire: American Journal of Science, v. 7, p. 468-476, 557-571.

Lahee, F.H., 1912, A new fossiliferous horizon on Blueberry Mountain [Walker Mountain], in Littleton, New Hampshire: Science, v. 36, p. 275-276.

Leo, G.W., 1985, Trondhjemite and metamorphosed quartz keratophyre tuff, of the Ammonoosuc Volcanics (Ordovician), western New Hampshire and adjacent Vermont and Massachusetts:

Geological Society of America Bulletin, v. 96, p. 1493-1507.

Leo, G.W., 1991, Oliverian domes, related plutonic rocks, and mantling Ammonoosuc Volcanics of the Bronson Hill anticlinorium, New England Appalachians: U.S. Geological Survey Professional Paper 1516, 92 p.

Lyons, J.B., Aleinikoff, J.N., and Zartman, R.E., 1986, Uranium-thorium-lead ages of the Highlandcroft Plutonic Suite, northern New England: American Journal of Science, v. 286, no. 6, p. 489-509.

Lyons, J.B., Bothner, W.A., Moench, R.H., and Thompson, J.B., Jr., 1997, Bedrock geologic map of New Hampshire: Reston, Va., U.S. Geological Survey, 2 sheets, scale 1:250,000 and 1:500,000.

Moench, R.H., 1971, Geologic map of the Rangeley and Phillips quadrangles, Franklin and Oxford Counties, Maine: U.S. Geological Survey Miscellaneous Geologic Investigations Map I-605, scale 1:62,500.

Moench, R.H., 1990, The Piermont allochthon, northern Connecticut Valley area, New England; preliminary description and resource implications, in Slack, J.F., ed., Summary results of the Glens Falls CUSMAP project, New York, Vermont, and New Hampshire: U.S. Geological Survey Bulletin 1887, p. J1-J23.

Moench, R.H., 1992, The "Piermont allochthon" in the Littleton-Moosilauke area of west-central New Hampshire; alternative interpretation-Reply: Geological Society of America Bulletin, v. 104, p. 1541-1545.

Moench, R.H., 1999, Nature of the Albee-Ammonoosuc contact in the Moore Reservoir area, New Hampshire and Vermont; Piermont-Frontenac allochthon, embattled but thriving!, in Wright, S.H., ed., Guidebook for field trips in Vermont and adjacent regions of New Hampshire and New York: Burlington, University of Vermont, New England Intercollegiate Geological Conference, $91^{\text {st }}$ Annual Meeting, p. 113-135.

Moench, R.H., and Aleinikoff, J.N., 2003, Stratigraphy, geochronology, and accretionary terrane settings of two Bronson Hill arc sequences, northern New England [part II]: Physics and Chemistry of the Earth, v. 28, nos. 1-3, p. 113-160.

Moench, R.H., Douglas-Hafner, K., Jahrling, I., and Pyke, A.R., 1987, Metamorphic stratigraphy of the classic Littleton area, New Hampshire, in Roy, D.C., ed., Geological Society of America, Northeastern Section, Geological Society of America Centennial Field Guide, v. 5, p. 247-256.

Moench, R.H., Boone, G.M., Bothner, W.A., Boudette, E.L., Hatch, N.L., Jr., Hussey, A.M., II, Marvinney, R.G., and Aleinikoff, J.N., 1995, Geologic map of the Sherbrooke-Lewiston area, Maine, New Hampshire, and Vermont, United States, and Québec, Canada: U.S. Geological Survey Miscellaneous Investigations Series Map I-1898-D, 2 sheets, scale 1:250,000, includes pamphlet, $56 \mathrm{p}$.

Moss, B.E., Haskin, L.A., and Dymek, R.F., 1996, Compositional variations in metamorphosed sediments of the Littleton Formation, New Hampshire, and the Carrabassett Formation, Maine, at sub-hand specimen, outcrop, and regional scales: American Journal of Science, v. 296, p. 473-505. 
Rankin, D.W., 1996, Bedrock geology of the Littleton, Vermont-New Hampshire 15-minute quadrangle northwest of the Ammonoosuc fault, in van Baalen, M.R., ed., Guidebook to field trips in northern New Hampshire and adjacent regions of Maine and Vermont: New England Intercollegiate Geological Conference, 88th Annual Meeting, Harvard University, Cambridge, Mass., p. 5-37.

Rankin, D.W., Coish, R.A., Tucker, R.D., Peng, Z.X., Wilson, S.A., and Rouff, A.A., 2007, Silurian extension in the Upper Connecticut Valley, United States and the origin of middle Paleozoic basins in the Québec embayment: American Journal of Science, v. 307, no. 1, p. 216-264.

Rankin, D.W., Tucker, R.D., and Amelin, Yuri, 2013, Reevaluation of the Piermont-Frontenac allochthon in the Upper Connecticut Valley; restoration of a coherent Boundary Mountains-Bronson Hill stratigraphic sequence: Geological Society of America Bulletin, v. 125, no. 5-6, p. 998-1024; doi:10.1130/B30590.1.

Ratcliffe, N.M., Stanley, R.S., Gale, M.H., Thompson, P.J., and Walsh, G.J., 2011, Bedrock geologic map of Vermont: U.S. Geological Survey Scientific Investigations Map 3184, 3 sheets, scale 1:100,000.

Ross, C.P., 1923, The geology of part of the Ammonoosuc mining district, New Hampshire: American Journal of Science, v. 5, p. 267-302.

Stose, G.W., and Ljungstedt, O.A., 1932, comps., Geologic map of the United States: U.S. Geological Survey, 4 sheets, scale 1:2,500,000.

Thompson, J.B., Jr., and Norton, S.A., 1968, Paleozoic regional metamorphism in New England and adjacent areas, in Zen, E-an, White, W.S., Hadley, J.B., and Thompson, J.B., Jr., eds., Studies of Appalachian geology; northern and maritime: New York, Interscience Publishers, p. 319-327.

White, W.S., 1968, Marland Pratt Billings—an appreciation, in Zen, E-an, White, W.S., Hadley, J.B., and Thompson, J.B., Jr., eds., Studies of Appalachian geology; northern and maritime: New York, Interscience Publishers, p. xi-xv. 
ISSN 2331-1258 (online)

http://dx.doi.org/10.3133/ofr20141026 